\title{
Implementation of qualification benches according to NF X 15-113
}

\author{
Georgin $\mathrm{E}^{1 \mathrm{a}}$, Bondoux $\mathrm{B}^{1}$, Bernard $\mathrm{N}^{1}$, Salem $\mathrm{M}^{1}$, Favreau $\mathrm{JO}^{1}$ \\ Allan $\mathrm{D}^{2}$, Spencer $\mathrm{R}^{2}$, Bossennec $\mathrm{V}^{3}$ \\ ${ }^{1}$ CETIAT, 25 avenue des arts - BP 52042, 69603 Villeurbanne, France \\ ${ }^{2}$ Michell Instruments Ltd, 48 Lancaster Way Business Park, Ely Cambs, CB6 3NW, United Kingdom \\ ${ }^{3}$ Michell Instruments SAS, 2-4 rue Jean Desparmet, 69008 Lyon, France
}

\begin{abstract}
Résumé. Afin d'estimer, le mieux possible, les erreurs de justesse des appareils en étalonnage, les laboratoires recherchent à générer des environnements le mieux contrôlés possible.. Les mesures d'humidité, en milieu industriel, sont très éloignées de ces conditions d'étalonnage en laboratoire. Ainsi, même si l'étalonnage constitue un point de départ nécessaire pour maitriser son processus de mesure, il ne permet pas toujours une description complète de la réponse ou du comportement de l'instrument. La norme française NF X15-113 [1] propose des essais complémentaires visant à parfaire la description de la réponse ou du comportement d'un hygromètre. Elle présente une série d'essais visant à qualifier les hygromètres à variation d'impédance de type capacitif ou résistif. La partie technique de la norme, exposant les essais à conduire, se compose de deux paragraphes: le premier est dédié aux essais génériques du capteur en humidité et en température notamment; le deuxième porte davantage sur les erreurs/effets liées aux facteurs d'influence. Dans le cadre du développement d'un hygromètre, spécifiquement adapté à l'industrie du secteur nucléaire, la société Michell Instruments et le CETIAT ont collaboré à la mise en œuvre le plus largement possible des essais proposés par la NF X15-113. Le CETIAT a ainsi développé spécialement des bancs d'essais visant à réaliser les essais en humidité et en température qui y sont décrits. Cet article présente les principes, les conditions environnantes, les séquences et les conditions des essais permettant d'appliquer cette norme. Nous pourrons distinguer les essais réalisés dans des conditions statiques ou d'équilibre: les étalonnages initiaux et finaux, les essais sur le domaine des températures nominales, et limites, les essais de dérive thermique du conditionneur de signal; le but de ces essais est d'établir l'erreur de justesse de l'instrument lorsqu'il est exposé aussi bien dans des conditions normales de température que dans des conditions extrêmes de température et d'humidité. Ensuite, nous pourrons distinguer les essais réalisés dans des conditions dynamiques ou transitoires: temps réponse suite à l'application d'un échelon d'humidité, où à l'application d'un échelon de température; le but de ces essais est d'étudier la réponse de l'hygromètre en essais lors de l'application de stimuli transitoires en température et en humidité. Enfin nous distinguerons les essais permettant d'évaluer le temps de récupération de l'instrument suite à la formation de condensation ou suite à l'immersion de l'hygromètre; le but de ces essais est de détecter toute dérive, réversible ou permanente, suite à l'exposition à l'eau de l'élément sensible. Ce travail se concentre sur les points clés de chaque essai et l'intérêt qu'il peut représenter pour l'utilisateur final lorsque son instrumentation est confrontée à ces conditions. Une attention particulière est portée sur les astuces et les difficultés pouvant survenir lors de la réalisation de ces essais.
\end{abstract}

\section{Introduction}

For the needs of its customers, working in the field of nuclear industry, Michell Instruments Ltd has designed and developed an hygrometer meeting the specifications required by the end users. For proving the hygrometer's performances were in compliance with the specifications, Michell Instruments Ltd has carried out a qualification program covering: initial reference tests, extreme operating conditions tests, EMC tests, tests relating to robustness and/or equipment behaviour over time, seismic test, and final reference tests.

This article present mainly the initial reference tests, extreme operating conditions tests, and final reference tests that have been performed at CETIAT with 6 hygrometers.

\subsection{Hygrometer description}

The hygrometer is the T300 RH Probe and transmitter designed, developed and manufactured by Michell Instruments Ltd.

\footnotetext{
${ }^{\mathrm{a}}$ Corresponding author: eric.georgin@cetiat.fr
} 


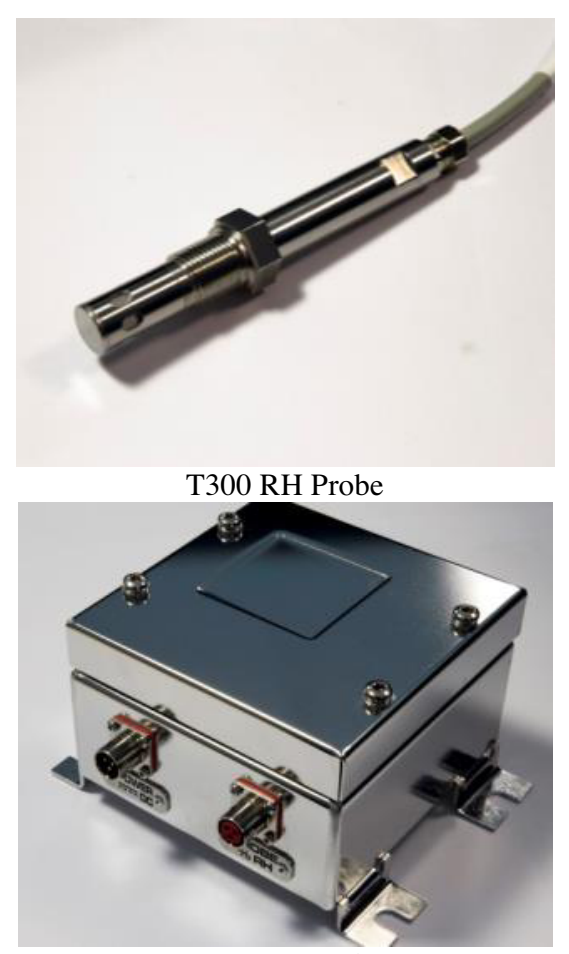

T300 Transmitter / signal conditionner

Figure 1 Pictures of T300 Humidity Transmitter

The T300 Humidity Transmitter has a measurement principle based on an interchangeable capacitive module (i7000) and provides a current output proportional to the relative humidity. The transmitter does not contain any programmable electronic components.

The device has been designed to meet qualification safety class requirements of customer's design code. The transmitter electronics are housed within an IP65 316 stainless steel enclosure with 4 off integral wall mountings. Connection is through Souriau type qualified connectors. Power input is 10-30 VDC and output is 4$20 \mathrm{~mA}$ loop powered (equivalent to $0-100 \% \mathrm{fs}$ or 0 $100 \% \mathrm{rh}$ ). The measurement range is limited to $5-95 \% \mathrm{rh}$, beyond which the sensor cannot accurately determine humidity levels.

\subsection{Hygrometer performances}

- Measurement range 5-95\%rh

- Temperature range: $0-70^{\circ} \mathrm{C}$

- Accuracy:

Process temperature

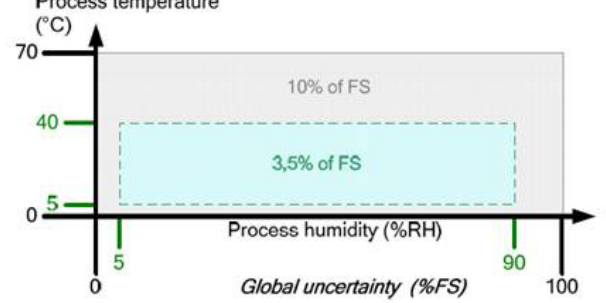

Figure 2 Accuracy of the Sensor Depending on Temperatures

- Response time: $90 \%$ of step change in less than 2 minutes

- Electrical Input/Output:

Output signal 4-20 mA

Supply Voltage 10-30 VDC
- Mechanical characteristics: Transmitter Enclosure material: AISI 316 stainless steel Dimensions: $150 \times 150 \times 107 \mathrm{~mm}$ Enclosure weight: $2,2 \mathrm{~kg}$ Protection: IP65

- Mechanical characteristics: Sensor Probe material: AISI 316 Stainless Steel Dimensions: $167 \mathrm{~mm} \mathrm{x} \propto 18 \mathrm{~mm}$ Probe weight: $200 \mathrm{~g}$

Cable type: Braided Polyolefin, screened 4 way Cable length: $2 \mathrm{~m}$ and $10 \mathrm{~m}$ according to the use.

\section{Tests performed}

The configuration of the test samples is identical to mass-produced equipment. Six test samples, identified as samples 1 (10 m cable), sample 2 (10 m Cable), sample 3 (2 m Cable), sample 4 (10 m Cable), sample 5 (2 m Cable) and sample 6 ( $2 \mathrm{~m}$ Cable), have been tested. Each sample comprises of three major components; Transmitter, Cable and Probe. For the various qualification tests mentioned in this work the device under test (DUT) or device under calibration (DUC) may have one or all of the component parts in the test environment and therefore the particular DUT have been specified for each test or series of tests.

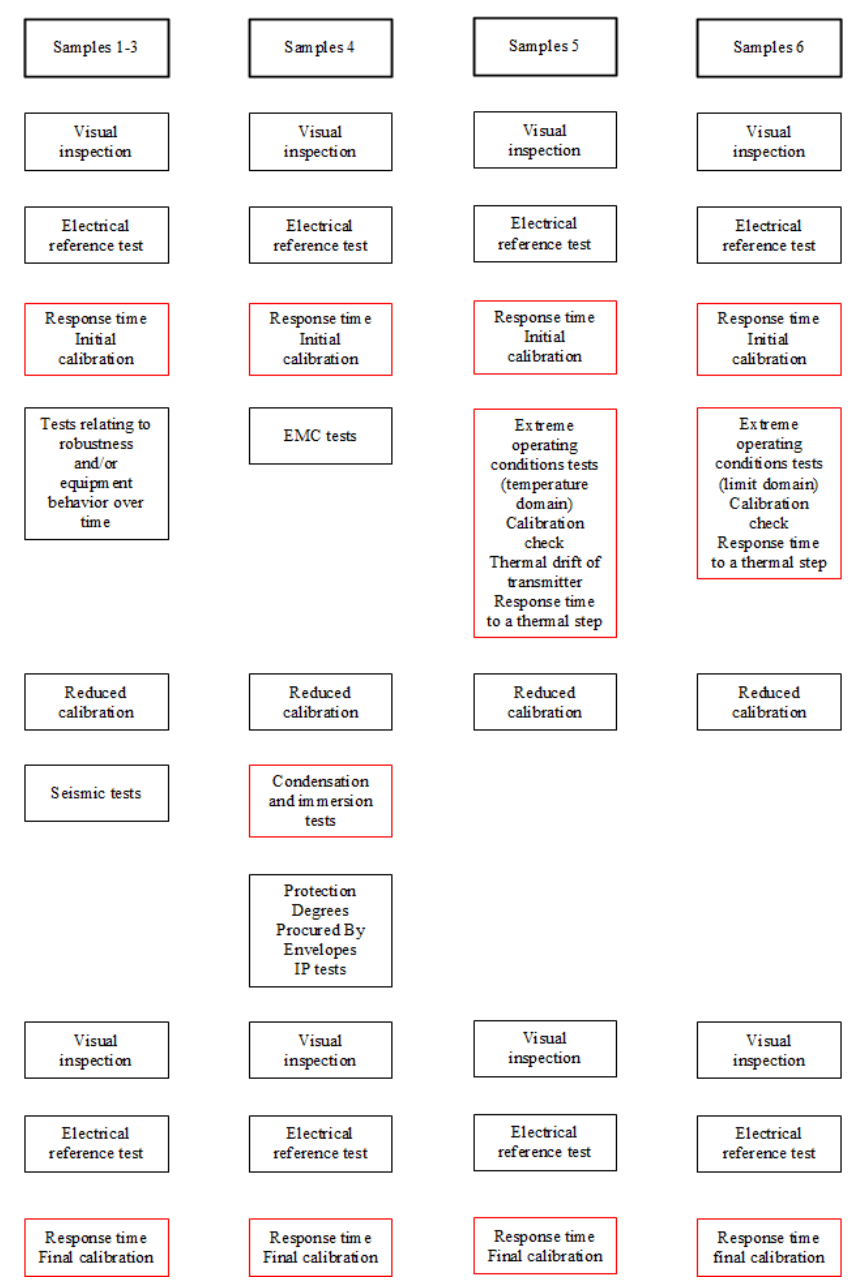

Figure 3 Qualification test sequence 
Qualification program includes: initial reference tests, extreme operating conditions tests, EMC tests, tests relating to robustness and/or equipment behaviour over time, seismic test, and final reference tests. In Figure 3, calibrations and tests performed at CETIAT are framed in red.

\subsection{Reference tests}

These tests aimed to establish the initial hygrometers' performances at the beginning of the test sequence, in terms of response time and calibration. Then, when performed at the end of the test sequence, aimed to determine any drift or modification of the hygrometers' performances.

\subsubsection{Response time}

The aim of this test is to measure the response time of the humidity sensor consequently to a change in humidity level. Facility that has been used is described in references [5], nevertheless a diagram of the calibration bench is proposed just below.
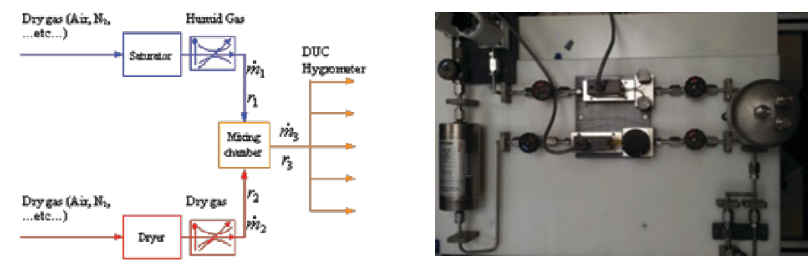

Figure 4 Diagram and pictures of the response time bench

Calibration rig is composed by a humid gas line and a dry gas line. By controlling the mixing ratio between the humid gas flow and the dry gas flow the desired humidity level is delivered to the DUC. The humidity step, or level, is controlled with the adjustment of the flows from the humid gas and the dry gas. Advantage of this method is that generation of humidity step, or level, does not imply probe removing.

The test sequence is the following:

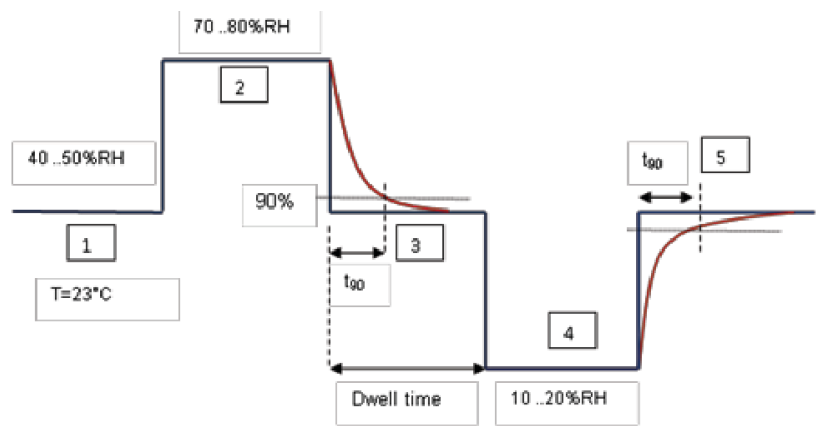

Figure 5 Humidity steps, or levels, applied; blue line ideal step applied / red line typical response expected from hygrometer

According to standard NF-X-15-113, the dwell time, at each stage from 1 to 5 , is not lower than at least ten times the response time of the humidity probe

- Stage 1: the test rig delivers the conditions of "normal test temperature", i.e. $23^{\circ} \mathrm{C} \pm 2^{\circ} \mathrm{C}$, and a humidity level such as $40 \% r h \leq U_{W} \leq 50 \% r h$, the DUC dwells in this normal conditions during 20 $\min$

- Stage 2: the test rig generates a "high" humidity level, i.e. $23^{\circ} \mathrm{C} \pm 2^{\circ} \mathrm{C}$, and $70 \% r h \leq U_{W} \leq 80 \% r h$, the DUC remains in these conditions during 20 $\min$

- Stage 3: the test rig delivers the conditions of "normal test temperature", i.e. $23^{\circ} \mathrm{C} \pm 2^{\circ} \mathrm{C}$, and a humidity level such as $40 \% r h \leq U_{W} \leq 50 \% r h$, the DUC dwells in this normal conditions during 20 $\min$

- Stage 4: the test rig generates a "low" humidity level, i.e. $23^{\circ} \mathrm{C} \pm 2^{\circ} \mathrm{C}$, and $10 \% r h \leq U_{W} \leq 20 \% r h$, the DUC remains in these conditions during 20 $\min$

- Stage 5: the test rig delivers the conditions of "normal test temperature", i.e. $23^{\circ} \mathrm{C} \pm 2^{\circ} \mathrm{C}$, and a humidity level such as $40 \% r h \leq U_{W} \leq 50 \% r h$, the DUC dwells in this normal conditions during 20 $\min$

Two responses times $t_{90}$ will be determined when the DUC reaches to the normal conditions: i.e. between stage 2 and stage $3\left(\mathrm{t}_{\mathrm{Hd}}\right)$, and between stage 4 and stage $5\left(\mathrm{t}_{\mathrm{Hm}}\right)$. The $t_{90}$ is the time at which $90 \%$ of the step amplitude is reached. This complete cycle, i.e. from stage 1 to 5 , is repeated three times. The DUC is tested without its filter (two times) and with its filter (one time). Typical response chart obtained, for initial and final calibration is presented below.

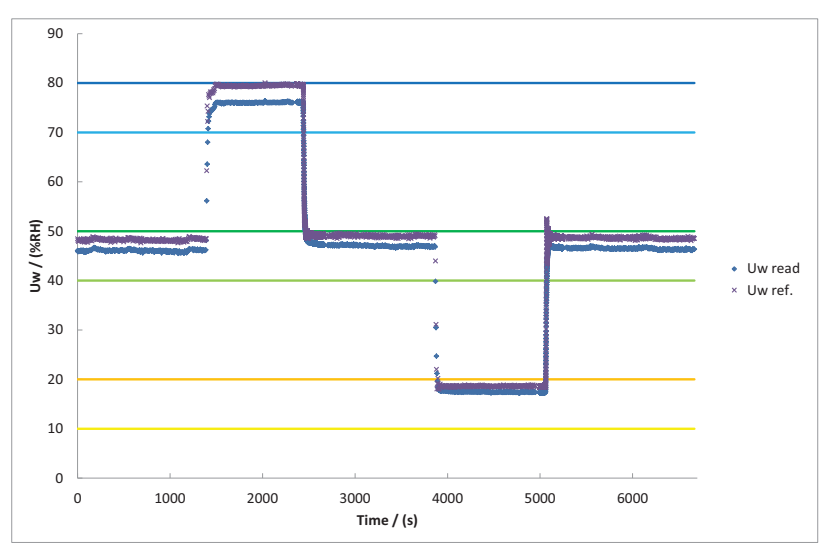

Figure 6 Humidity recorded for reference (blue) and DUC (purple)

\begin{tabular}{|c|c|c|c|c|c|c|}
\hline Cycle & DUC & DUC & DUC & DUC & DUC & DUC \\
\hline $\begin{array}{r}\text { Cycle } \\
1 \mathrm{t}_{\mathrm{Hd}}\end{array}$ & $\approx 24 \mathrm{~s}$ & $\approx 26 \mathrm{~s}$ & $\approx 25 \mathrm{~s}$ & $\approx 26 \mathrm{~s}$ & $\approx 26 \mathrm{~s}$ & $\approx 23 \mathrm{~s}$ \\
\hline $\begin{array}{r}\text { Cycle } \\
1 \mathrm{t}_{\mathrm{Hm}}\end{array}$ & $\approx 19 \mathrm{~s}$ & $\approx 20 \mathrm{~s}$ & $\approx 19 \mathrm{~s}$ & $\approx 20 \mathrm{~s}$ & $\approx 21 \mathrm{~s}$ & $\approx 20 \mathrm{~s}$ \\
\hline $\begin{array}{r}\text { Cycle } \\
2 \mathrm{t}_{\mathrm{Hd}}\end{array}$ & $\approx 24 \mathrm{~s}$ & $\approx 26 \mathrm{~s}$ & $\approx 25 \mathrm{~s}$ & $\approx 25 \mathrm{~s}$ & $\approx 25 \mathrm{~s}$ & $\approx 23 \mathrm{~s}$ \\
\hline $\begin{array}{c}\text { Cycle } \\
2 \mathrm{t}_{\mathrm{Hm}}\end{array}$ & $\approx 21 \mathrm{~s}$ & $\approx 21 \mathrm{~s}$ & $\approx 19 \mathrm{~s}$ & $\approx 18 \mathrm{~s}$ & $\approx 21 \mathrm{~s}$ & $\approx 20 \mathrm{~s}$ \\
\hline \hline $\begin{array}{c}\text { Cycle } \\
3 \mathrm{t}_{\mathrm{Hd}}\end{array}$ & $\approx 39 \mathrm{~s}$ & $\approx 34 \mathrm{~s}$ & $\approx 33 \mathrm{~s}$ & $\approx 35 \mathrm{~s}$ & $\approx 38 \mathrm{~s}$ & $\approx 34 \mathrm{~s}$ \\
\hline $\begin{array}{c}\mathrm{Cycle} \\
3 \mathrm{t}_{\mathrm{Hm}}\end{array}$ & $\approx 25 \mathrm{~s}$ & $\approx 25 \mathrm{~s}$ & $\approx 24 \mathrm{~s}$ & $\approx 23 \mathrm{~s}$ & $\approx 28 \mathrm{~s}$ & $\approx 26 \mathrm{~s}$ \\
\hline
\end{tabular}

Cycle 1 and cycle 2 performed without filter

Cycle 3 performed with filter

Table 1 Typical results obtained 
We can notice that:

- The response time measured by DUC is bigger for humidity decreases than for humidity increases.

- Response time measured by DUC is bigger with filter than without filter.

- Results are in good agreement with manufacturer specifications.

\subsubsection{Calibration}

The aim of the calibration is to establish, under specified conditions, a relation between the quantity values with measurement uncertainties provided by measurement standards and corresponding indications with associated measurement uncertainties. The calibration is performed according to NF X 15 - 113 at the reference temperature of $23^{\circ} \mathrm{C} \pm 2{ }^{\circ} \mathrm{C}$. DUC are preconditioned for 24 hours at $50^{\circ} \mathrm{C} 85 \%$ rh immediately before the calibration begins. The acceptance criteria for the initial and final calibrations are given by the performance requirements stated in the technical specification Figure 2.

Facilities that have been used are humid air generator (HAG), developed by LNE-CETIAT, and thermostatic chamber. These facilities are described in references [3], [4] and [5], nevertheless a diagram of the calibration bench is proposed just below.

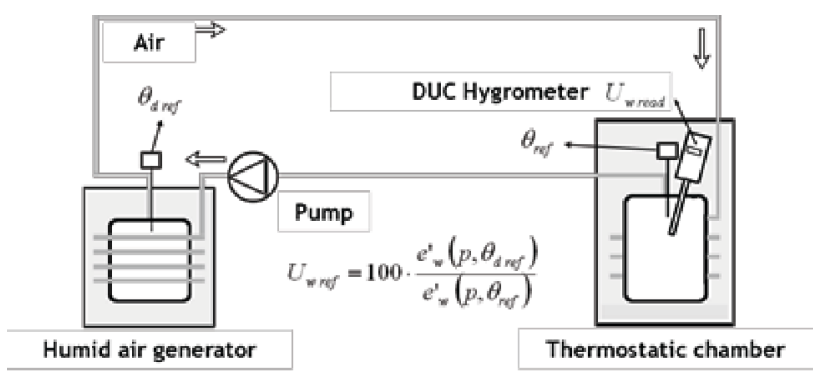

Principle diagram of two temperatures HAG working in a closed loop system

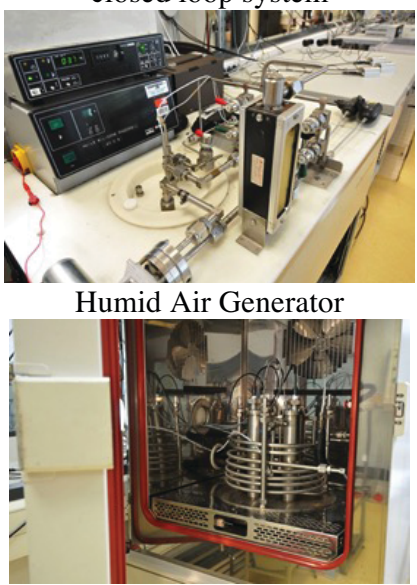

Thermostatic chamber with testing chamber where DUC is housed

Figure 7 Diagram and pictures of the calibration bench

The DUC are exposed to 9 points calibration program: $5 \%$ rh $-25 \%$ rh $-50 \%$ rh $-75 \%$ rh $-95 \%$ rh $75 \%$ rh $-50 \%$ rh $-25 \%$ rh $-5 \%$ rh @ $23^{\circ} \mathrm{C} \pm 2{ }^{\circ} \mathrm{C}$. Typical response chart obtained, for initial and final calibration is presented below.

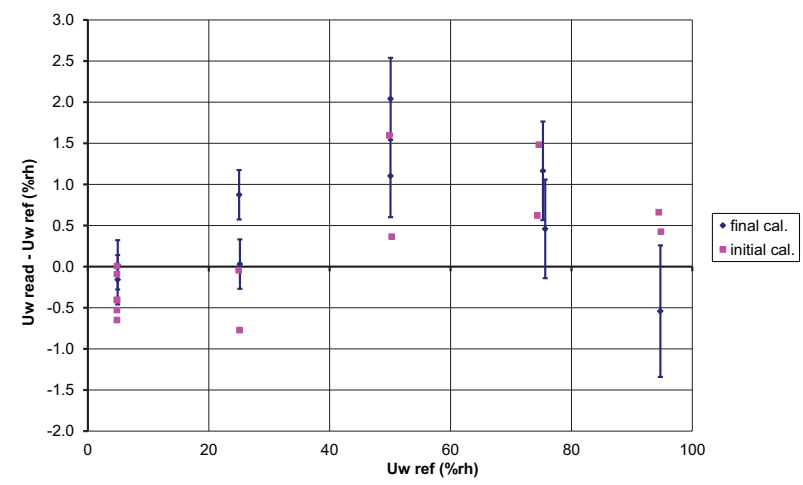

Figure 8 Sample results obtained during initial (pink) and final (blue) calibration

These results are in good agreement with manufacturer specifications, see Figure 2.

\subsection{Extreme operating conditions tests}

\subsubsection{Test in the temperature domain}

The aim of this test is to exposed the humidity probe to a cycle which combines values of relative humidity and dry temperature. Response signal is compared to laboratory reference values.

Facilities that have been used are HAG and thermostatic chamber, similar to those that have been used for calibration. These facilities are presented below.

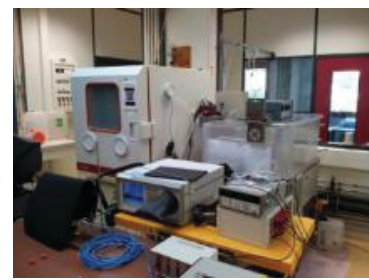

HAG and thermostatic chamber - front view

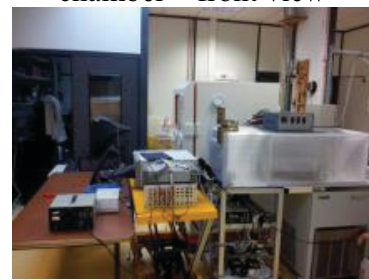

HAG and thermostatic chamber - side view

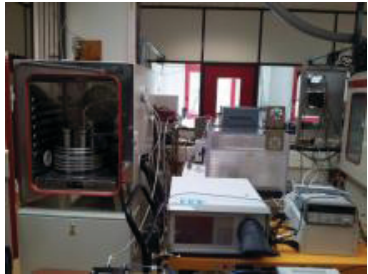

HAG and thermostatic chamber - front view

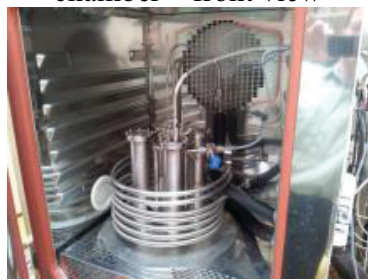

testing chamber where DUC is housed
Figure 9 HAG and thermostatic chamber

According to NF $\mathrm{X} 15-113$, test sequence is: 

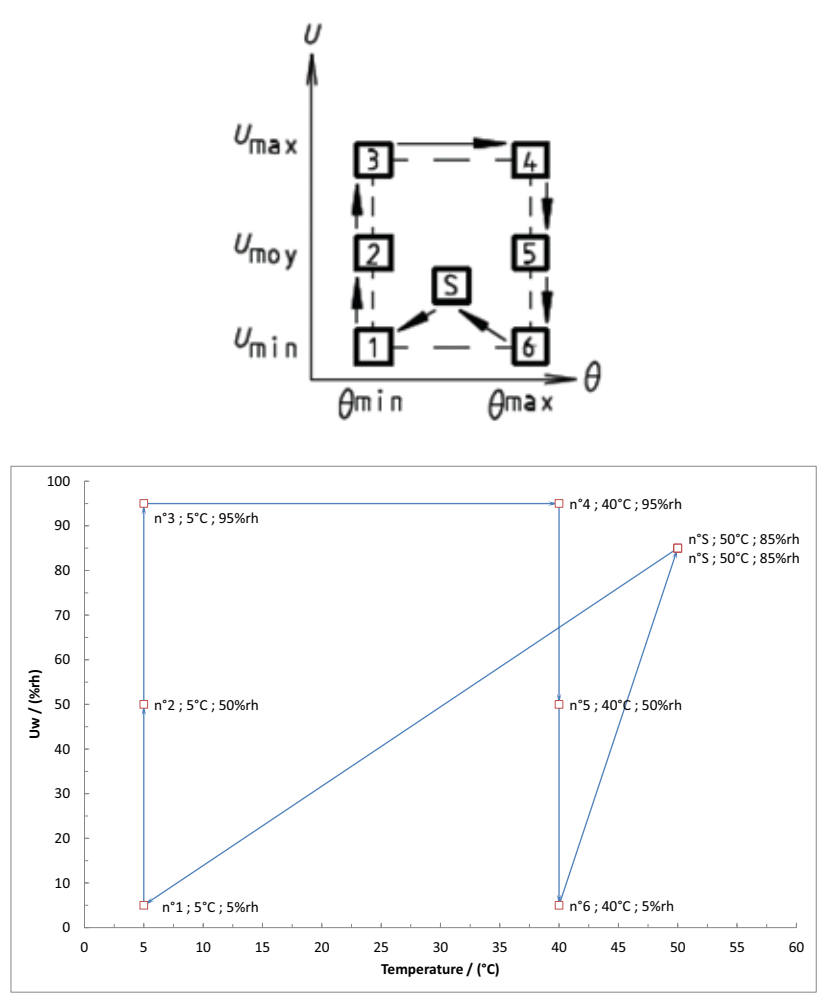

Figure 10 Climatogramme: theorical (NF X15-113) and applied according manufacturer specification for temperature domain

A great care has been brought in order to avoid any parasite condensation while performing the test sequence.

Relative humidity
\begin{tabular}{|c|c|c|c|c|c|c|}
\hline $\begin{array}{c}\text { Point } \\
\text { number }\end{array}$ & $\begin{array}{c}\text { Uw ref } \\
(\% \mathrm{RH})\end{array}$ & $\begin{array}{c}\text { Uw read } \\
(\mathrm{mA})\end{array}$ & $\begin{array}{c}\text { Uw read converted } \\
(\% \mathrm{RH})\end{array}$ & $\begin{array}{c}\text { Uw read - Uw ref } \\
(\% \mathrm{RH})\end{array}$ & $\begin{array}{c}\text { Calibration } \\
\text { uncertainty }(\% \mathrm{RH})\end{array}$ & $\begin{array}{c}\theta \text { ref } \\
\left({ }^{\circ} \mathrm{C}\right)\end{array}$ \\
\hline $\mathrm{S}$ & 84.4 & 17.027 & 81.4 & -3.0 & 0.7 & 49.98 \\
\hline 1 & 4.9 & 4.680 & 4.2 & -0.7 & 0.3 & 5.01 \\
\hline 2 & 50.1 & 11.764 & 48.5 & -1.5 & 0.7 & 5.02 \\
\hline 3 & 95.0 & 18.446 & 90.3 & -4.7 & 0.9 & 4.99 \\
\hline 4 & 95.5 & 19.050 & 94.1 & -1.5 & 0.7 & 39.98 \\
\hline 5 & 49.9 & 11.779 & 48.6 & -1.2 & 0.5 & 39.95 \\
\hline 6 & 4.9 & 4.702 & 4.4 & -0.5 & 0.3 & 39.96 \\
\hline $\mathrm{S}$ & 84.8 & 17.141 & 82.1 & -2.6 & 0.7 & 49.99 \\
\hline
\end{tabular}

Uw ref $(\% \mathrm{RH})$ : Reference in relative humidity

$\theta \operatorname{ref}\left({ }^{\circ} \mathrm{C}\right)$ : Reference in dry temperature

Uw read (mA) : Analog output of DUC for relative humidity

Uw read converted (\%HR) : Analog output of DUC converted in relative humidity

Table 2 Sample results obtained during the test in the temperature domain

A great care has been brought in order to avoid any parasite condensation while performing the test sequence.

All the points are equal or lower than manufacturer specifications, see Figure 2.

\subsubsection{Tests in the limit domain}

The aim and facilities are the same than those presented in $\S 3.2 .1$. Nevertheless, according to NF X 15113 , test test sequence is different and cover the extreme temperatures values at which the hygrometer can be used:
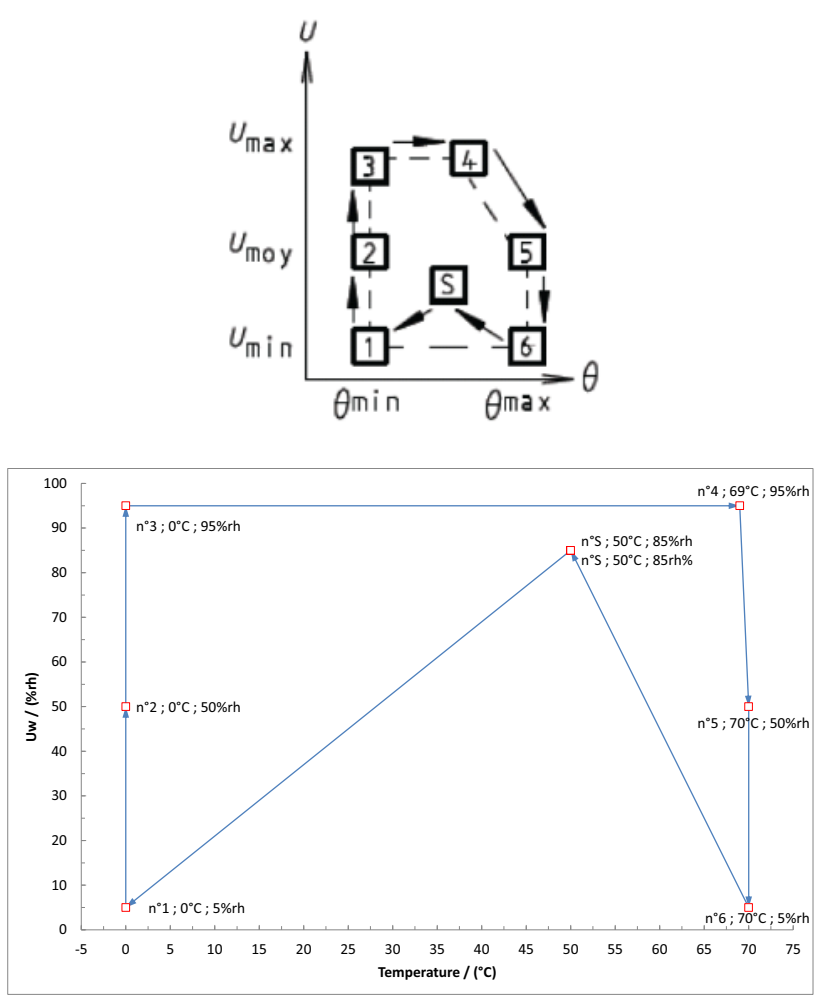

Figure 11 Climatogramme: theorical (NF X15-113) and applied according manufacturer specification for limit domain

Humidité relative
\begin{tabular}{|c|c|c|c|c|c|c|}
\hline $\begin{array}{c}\text { Point } \\
\text { number }\end{array}$ & $\begin{array}{c}\text { Uw ref } \\
(\% \mathrm{RH})\end{array}$ & $\begin{array}{c}\text { Uw read } \\
(\mathrm{mA})\end{array}$ & $\begin{array}{c}\text { Uw read converted } \\
(\% \mathrm{RH})\end{array}$ & $\begin{array}{c}\text { Uw read - Uw ref } \\
(\% \mathrm{RH})\end{array}$ & $\begin{array}{c}\text { Calibration } \\
\text { uncertainty }(\% \mathrm{RH})\end{array}$ & $\begin{array}{c}\theta \text { ref } \\
\left({ }^{\circ} \mathrm{C}\right)\end{array}$ \\
\hline $\mathrm{S}$ & 85.2 & 17.137 & 82.1 & -3.1 & 0.7 & 49.98 \\
\hline 1 & 4.9 & 4.570 & 3.6 & -1.3 & 0.3 & 0.07 \\
\hline 2 & 50.0 & 11.632 & 47.7 & -2.3 & 0.7 & 0.08 \\
\hline 3 & 95.4 & 18.435 & 90.2 & -5.2 & 1.2 & 0.06 \\
\hline 4 & 94.9 & 18.687 & 91.8 & -3.1 & 0.6 & 68.92 \\
\hline 5 & 49.7 & 11.575 & 47.3 & -2.4 & 0.4 & 69.90 \\
\hline 6 & 4.9 & 4.803 & 5.0 & 0.1 & 0.3 & 69.91 \\
\hline $\mathrm{S}$ & 84.9 & 17.459 & 84.1 & -0.8 & 0.7 & 49.92 \\
\hline
\end{tabular}

Uw ref $(\% \mathrm{RH})$ : Reference in relative humidity

$\theta \operatorname{ref}\left({ }^{\circ} \mathrm{C}\right)$ : Reference in dry temperature

Uw read (mA) : Analog output of DUC for relative humidity

Uw read converted (\%HR) : Analog output of DUC converted in relative humidity

Table 3 Sample result obtained during the test in thelimit domain

A great care has been brought in order to avoid any parasite condensation while performing the test sequence.

All the points, except $n^{\circ} 3$, are equal or lower than manufacturer specifications, see Figure 2.

\subsubsection{Thermal drift of the transmitter}

The aim of this test is to expose the humidity probe to a cycle which combines values of relative humidity and dry temperature, identical to climatogramme presented in Figure 10. This cycle is repeated for three different temperature levels of the T300 transmitter or signal conditioner. Readings are compared to the laboratory reference values.

Facilities are the same than those presented in § 3.2.1. with an additional thermostatic chamber for thermalizing the signal conditioner. 


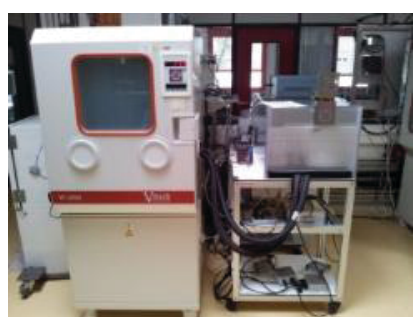

HAG and thermostatic chamber - front view

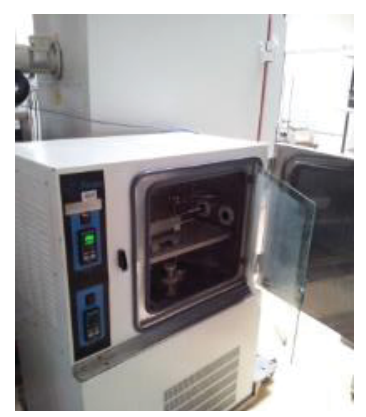

thermostatic chamber for transmitter

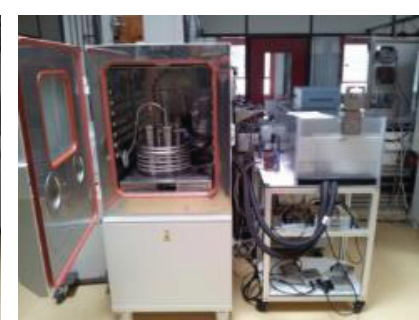

HAG and thermostatic chamber - front view

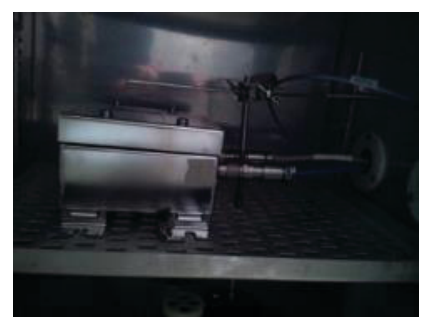

Transmitter with Pt 100 probe in thermostatic chamber
Figure 12 HAG and thermostatic chamber

According to NF X 15-113, the test sequence, applied to the humidity probe, is the same than the one presented in Figure 10.

Relative humidity
\begin{tabular}{|c|c|c|c|c|c|c|c|}
\hline $\begin{array}{c}\text { Point } \\
\text { number }\end{array}$ & $\begin{array}{c}\text { Uw ref } \\
(\% \mathrm{RH})\end{array}$ & $\begin{array}{c}\text { Uw read } \\
(\mathrm{mA})\end{array}$ & $\begin{array}{c}\text { Uw read converted } \\
(\% \mathrm{OWH})\end{array}$ & $\begin{array}{c}\text { Uw read - Uw ref } \\
(\% \mathrm{RH})\end{array}$ & $\begin{array}{c}\text { Calibration } \\
\text { uncertainty }(\% \mathrm{RH})\end{array}$ & $\begin{array}{c}\theta \text { ref } \\
\left({ }^{\circ} \mathrm{C}\right)\end{array}$ & $\begin{array}{c}\theta \text { transmitter } \\
\left({ }^{\circ} \mathrm{C}\right)\end{array}$ \\
\hline 1 & 84.8 & 17.030 & 81.4 & -3.3 & 0.7 & 50.01 & 5.10 \\
\hline 2 & 4.9 & 4.710 & 4.4 & -0.4 & 0.3 & 5.08 & 5.13 \\
\hline 3 & 50.0 & 11.814 & 48.8 & -1.1 & 0.7 & 4.94 & 5.16 \\
\hline 4 & 95.6 & 18.626 & 91.4 & -4.2 & 0.9 & 4.94 & 5.17 \\
\hline 5 & 94.8 & 19.036 & 94.0 & -0.9 & 0.7 & 39.98 & 5.16 \\
\hline 6 & 49.9 & 11.820 & 48.9 & -1.0 & 0.5 & 39.98 & 5.17 \\
\hline 7 & 4.9 & 4.697 & 4.4 & -0.6 & 0.3 & 39.98 & 5.06 \\
\hline 8 & 84.8 & 17.088 & 81.8 & -3.0 & 0.7 & 50.04 & 5.88 \\
\hline 9 & 84.7 & 17.103 & 81.9 & -2.8 & 0.7 & 50.03 & 23.14 \\
\hline 10 & 4.9 & 4.705 & 4.4 & -0.5 & 0.3 & 5.18 & 23.01 \\
\hline 11 & 49.9 & 11.840 & 49.0 & -0.9 & 0.7 & 4.94 & 23.02 \\
\hline 12 & 94.7 & 18.462 & 90.4 & -4.3 & 0.9 & 5.03 & 23.03 \\
\hline 13 & 94.8 & 18.967 & 93.5 & -1.3 & 0.7 & 39.96 & 23.32 \\
\hline 14 & 50.2 & 11.942 & 49.6 & -0.5 & 0.5 & 39.87 & 23.02 \\
\hline 15 & 4.9 & 4.708 & 4.4 & -0.5 & 0.3 & 39.97 & 23.02 \\
\hline 16 & 84.8 & 17.168 & 82.3 & -2.5 & 0.7 & 49.96 & 23.02 \\
\hline 17 & 84.9 & 17.109 & 81.9 & -3.0 & 0.7 & 50.03 & 40.14 \\
\hline 18 & 4.9 & 4.733 & 4.6 & -0.3 & 0.3 & 5.03 & 40.13 \\
\hline 19 & 49.9 & 11.894 & 49.3 & -0.6 & 0.7 & 4.95 & 40.14 \\
\hline 20 & 94.9 & 18.468 & 90.4 & -4.5 & 0.9 & 5.05 & 40.14 \\
\hline 21 & 95.2 & 19.033 & 94.0 & -1.2 & 0.7 & 39.88 & 40.03 \\
\hline 22 & 50.2 & 11.934 & 49.6 & -0.6 & 0.5 & 39.88 & 40.03 \\
\hline 23 & 4.9 & 4.710 & 4.4 & -0.5 & 0.3 & 39.98 & 40.03 \\
\hline 24 & 84.6 & 17.089 & 81.8 & -2.8 & 0.7 & 50.03 & 40.03 \\
\hline
\end{tabular}

Uw ref $(\% \mathrm{RH}):$ Reference in relative humidity

$\theta \operatorname{ref}\left({ }^{\circ} \mathrm{C}\right)$ : Reference in dry temperature

Uw read (mA) : Analog output of DUC for relative humidity

Uw read converted (\%HR) : Analog output of DUC converted in relative humidity

$\theta$ transmitter $\left({ }^{\circ} \mathrm{C}\right)$ : temperature of trans mitter

Table 4 Sample results obtained during the thermal drift of the transmitter test

All the points, are equal or lower than manufacturer specifications, see Figure 2.

\subsubsection{Response time due to a thermal step}

The aim of this test is to measure the response time of the humidity sensor consequently to a change in temperature level. First, the humidity sensor is stabilized at a constant temperature level. Then, at a given time, the temperature condition is changed in order to apply a fast variation in temperature to the humidity sensor. According to NF X 15-113, during this test relative the humidity level does not need to be kept constant.

The calibration bench is composed of a climatic chamber and a sliding actuator (carriage) which holds the DUC and allows its motion in both direction: from the internal part of the climatic chamber to the outside and vice versa. The signal conditioner remains outside of the climatic chamber in the ambient conditions of the laboratory.
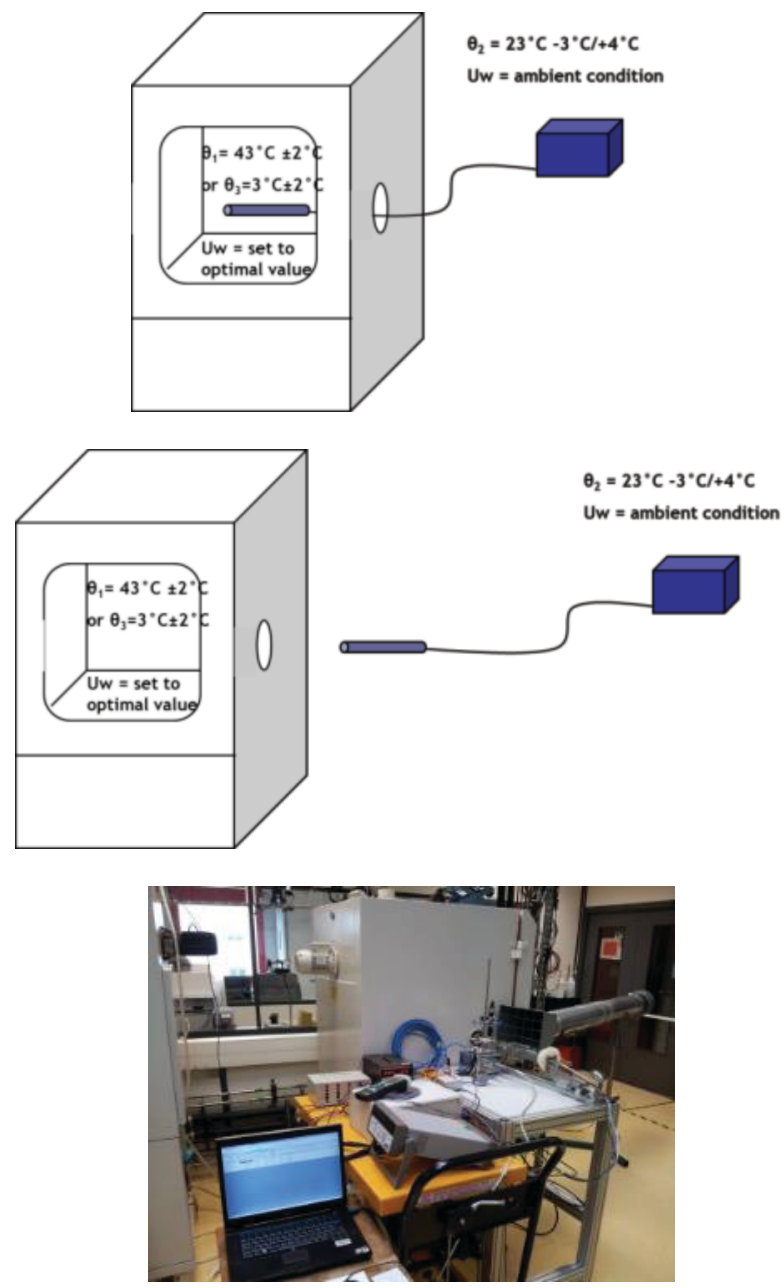

Facility composed by climatic chamber and device (carriage) which hold DUC

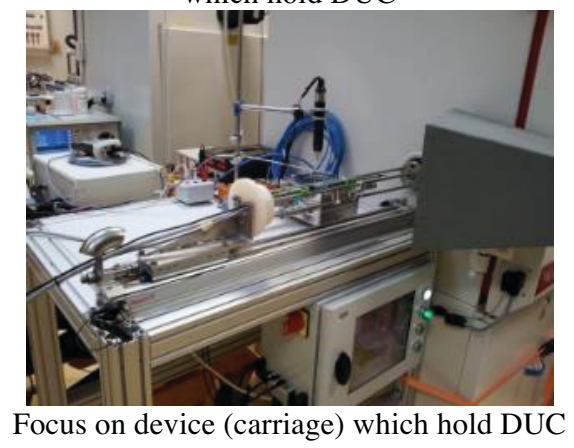

Figure 13 Diagrams and pictures of facility 
According to standard NF-X-15-113, the temperature step is applied while avoiding any condensation on the probe.

Realization of a temperature step of $-20^{\circ} \mathrm{C}$

- Stage 1: DUC is placed inside the climatic chamber set at $43^{\circ} \mathrm{C} \pm 2^{\circ} \mathrm{C}$ during at least 30 minutes

- Stage 2: DUC is moved at the ambient conditions of the laboratory, i.e. $23^{\circ} \mathrm{C}-3{ }^{\circ} \mathrm{C} /+4^{\circ} \mathrm{C}$, from $15 \%$ rh to $85 \%$ rh and atmospheric pressure during at least 30 minutes

Response time $t_{90}$ is determined when the DUC reaches stability: i.e. between stage 1 and stage $2\left(t_{T d}\right)$, The $t_{90}$ is the time at which $90 \%$ of the step amplitude is reached.

- Stage 3: DUC is exposed to the ambient conditions of the laboratory, i.e. $23^{\circ} \mathrm{C}-3^{\circ} \mathrm{C} /+4^{\circ} \mathrm{C}$, from $15 \%$ rh to $85 \%$ rh and atmospheric pressure during at least 30 minutes

- Stage 4: DUC is moved into the climatic chamber set at $3^{\circ} \mathrm{C} \pm 2^{\circ} \mathrm{C}$, during at least 30 minutes

Response time $\mathrm{t} 90$ is determined when the DUC reaches stability: i.e. between stage 3 and stage $4\left(t_{T d}\right)$.

Realization of a temperature step of $+20^{\circ} \mathrm{C}$

- Stage 5: DUC is kept at the ambient conditions of the laboratory, i.e. $23^{\circ} \mathrm{C}-3^{\circ} \mathrm{C} /+4^{\circ} \mathrm{C}$, from $15 \%$ rh to $85 \%$ rh and atmospheric pressure during at least 30 minutes

- Stage 6: DUC is moved into the climatic chamber set at $43^{\circ} \mathrm{C} \pm 2{ }^{\circ} \mathrm{C}$ and no higher than $30 \%$ rh during at least 30 minutes

Response time $t_{90}$ is determined when the DUC reaches stability: i.e. between stage 5 and stage $6\left(\mathrm{t}_{\mathrm{Tm}}\right)$.

- Stage 7: DUC is placed into the climatic chamber set at $3{ }^{\circ} \mathrm{C} \pm 2^{\circ} \mathrm{C}$, at least 30 minutes

- Stage 8: DUC is moved at the ambient conditions of the laboratory, i.e. $23^{\circ} \mathrm{C}-3^{\circ} \mathrm{C} /+4^{\circ} \mathrm{C}$ and no higher than $25 \%$ rh during at least 30 minutes

Response time $t_{90}$ is determined when the DUC reaches stability: i.e. between stage 7 and stage $8\left(\mathrm{t}_{\mathrm{Tm}}\right)$.

In the case where condensation risk is too high, stage 7 and 8 are not performed. This complete cycle, i.e. from stage 1 to 8 or from stage 1 to 6 , is repeated three times. The DUC has been tested without the filter (two times) and with filter (one time).

\begin{tabular}{|c|c|c|c|c|c|}
\hline & & $\begin{array}{c}1-2 \\
43^{\circ} \mathrm{C} \rightarrow 23^{\circ} \mathrm{C}\end{array}$ & $\begin{array}{c}3-4 \\
23^{\circ} \mathrm{C} \rightarrow 3^{\circ} \mathrm{C}\end{array}$ & $\begin{array}{c}5-6 \\
23^{\circ} \mathrm{C} \rightarrow 43^{\circ} \mathrm{C}\end{array}$ & $\begin{array}{c}\quad 7-8 \\
3^{\circ} \mathrm{C} \rightarrow 23^{\circ} \mathrm{C}\end{array}$ \\
\hline \multirow{2}{*}{$\begin{array}{l}\text { DUC (cycle 1) } \\
\text { without filter }\end{array}$} & $t_{T \text { TmouTd }}\left(U_{w D U C}\right)$ & $550 \mathrm{~s}$ & $952 \mathrm{~s}$ & $574 \mathrm{~s}$ & - \\
\hline & $t_{90 \%}\left(T_{\text {ref Duc }}\right)$ & $125 \mathrm{~s}$ & $182 \mathrm{~s}$ & $177 \mathrm{~s}$ & - \\
\hline \multirow{2}{*}{$\begin{array}{l}\text { DUC (cycle 2) } \\
\text { without filter }\end{array}$} & $t_{T m \text { ou Td }}\left(U_{w \text { DUC }}\right)$ & $536 \mathrm{~s}$ & $1167 \mathrm{~s}$ & $535 \mathrm{~s}$ & - \\
\hline & $t_{90 \%}\left(T_{\text {ref DuC }}\right)$ & $114 \mathrm{~s}$ & $168 \mathrm{~s}$ & $173 \mathrm{~s}$ & - \\
\hline \multirow{2}{*}{$\begin{array}{c}\text { DUC (cycle 3) } \\
\text { with filter }\end{array}$} & $t_{T \text { mouTd }}\left(U_{w \text { DUC }}\right)$ & $1185 \mathrm{~s}$ & $1676 \mathrm{~s}$ & $1126 \mathrm{~s}$ & - \\
\hline & $t_{90 \%}\left(T_{\text {ref DUC }}\right)$ & $103 \mathrm{~s}$ & $178 \mathrm{~s}$ & $192 \mathrm{~s}$ & - \\
\hline \multirow{2}{*}{$\begin{array}{l}\text { DUC (cycle 1) } \\
\text { without filter }\end{array}$} & $t_{T M \text { ouTd }}\left(U_{w \text { DUC }}\right)$ & $551 \mathrm{~s}$ & $922 \mathrm{~s}$ & $690 \mathrm{~s}$ & - \\
\hline & $t_{90 \%}\left(T_{\text {ref DuC }}\right)$ & $101 \mathrm{~s}$ & $185 \mathrm{~s}$ & $191 \mathrm{~s}$ & - \\
\hline \multirow{2}{*}{$\begin{array}{l}\text { DUC (cycle 2) } \\
\text { without filter }\end{array}$} & $t_{T M \text { ouTd }}\left(U_{w \text { DUC }}\right)$ & $584 \mathrm{~s}$ & $967 \mathrm{~s}$ & $635 \mathrm{~s}$ & - \\
\hline & $t_{90 \%}\left(T_{\text {ref DUC }}\right)$ & $148 \mathrm{~s}$ & $176 \mathrm{~s}$ & $182 \mathrm{~s}$ & - \\
\hline \multirow{2}{*}{$\begin{array}{c}\text { DUC (cycle 3) } \\
\text { with filter }\end{array}$} & $t_{\text {TMouTd }}\left(U_{w \text { DUC }}\right)$ & $1406 \mathrm{~s}$ & $1497 \mathrm{~s}$ & $1130 \mathrm{~s}$ & - \\
\hline & $t_{90 \%}\left(T_{\text {ref DUC }}\right)$ & $147 \mathrm{~s}$ & $171 \mathrm{~s}$ & $184 \mathrm{~s}$ & - \\
\hline
\end{tabular}

Table 5 Typical results obtained

Typical response chart obtained, for initial and final calibration is presented below.
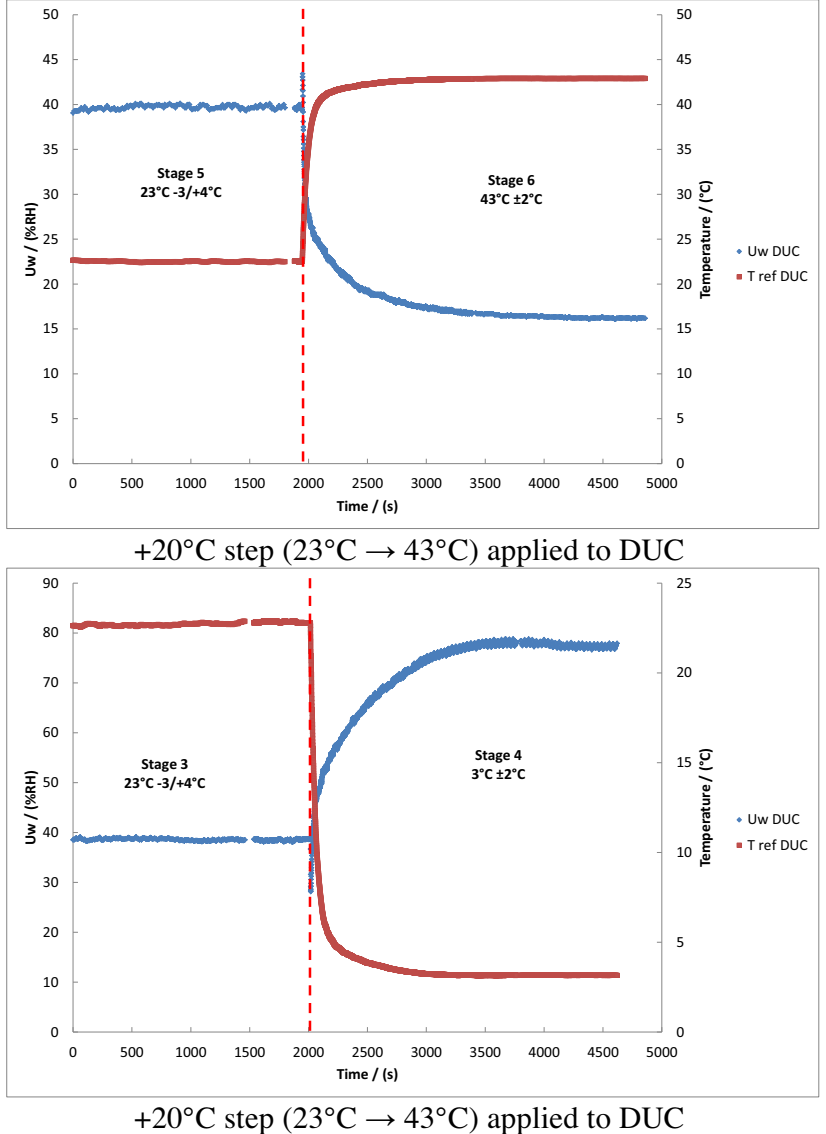

Figure 14 Reference temperature measured with Pt 100 set close to DUC (red) relative humidity measured with DUC (blue)

For each hygrometers, the response time due to a thermal step is higher when the filter is used than without. The response time appears higher at low temperature than at medium or high temperature, typically :

$\mathrm{t}_{\mathrm{Td}}\left(\mathrm{U}_{\mathrm{w} \text { DUC }} ; 23^{\circ} \mathrm{C} \rightarrow 3^{\circ} \mathrm{C}\right)>\mathrm{t}_{\mathrm{Td}}\left(\mathrm{U}_{\mathrm{w} \text { DUC }} ; 23^{\circ} \mathrm{C} \rightarrow 43^{\circ} \mathrm{C}\right)$ or $\mathrm{t}_{\mathrm{Tm}}\left(\mathrm{U}_{\mathrm{w} \text { DUC }} ; 43^{\circ} \mathrm{C} \rightarrow 23^{\circ} \mathrm{C}\right)$

\subsubsection{Withstanding to condensation}

The aim of this test is to qualify the resilience capability of the humidity probe consequently to an accidental condensation. The humidity probe is set at $0^{\circ} \mathrm{C}$ and after a dwell time, moved into ambient conditions of the laboratory, i.e. $23^{\circ} \mathrm{C}-3^{\circ} \mathrm{C} /+4^{\circ} \mathrm{C}$, from $15 \%$ rh to $85 \%$ rh and atmospheric pressure.

The calibration rig is composed by a climatic chamber and a sliding actuator which hold DUC and allows the motion of DUC from the internal part of climatic chamber to the outside. The signal conditioner remains outside of the climatic chamber, in the ambient conditions of the laboratory. 

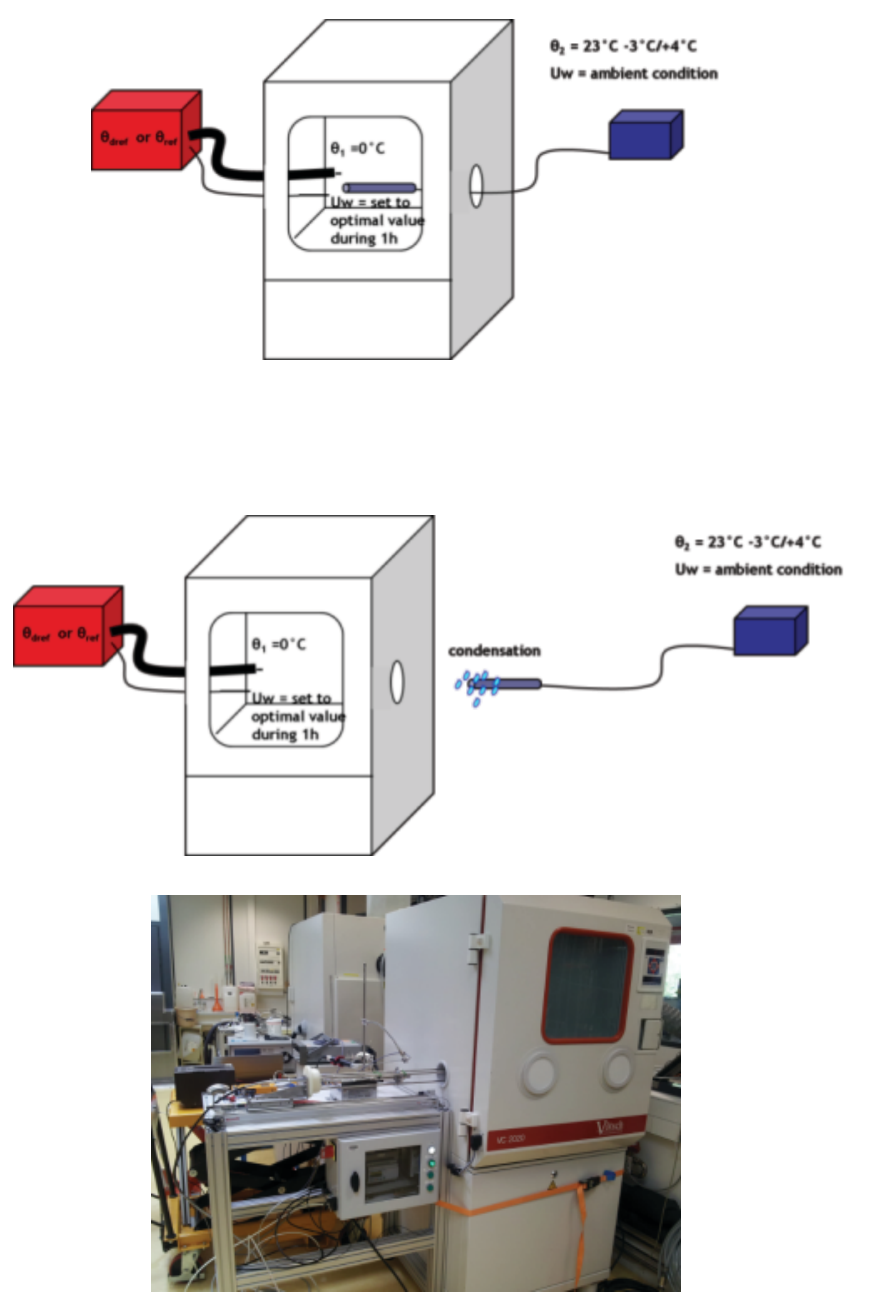

Facility composed by climatic chamber and device (carriage) which hold DUC

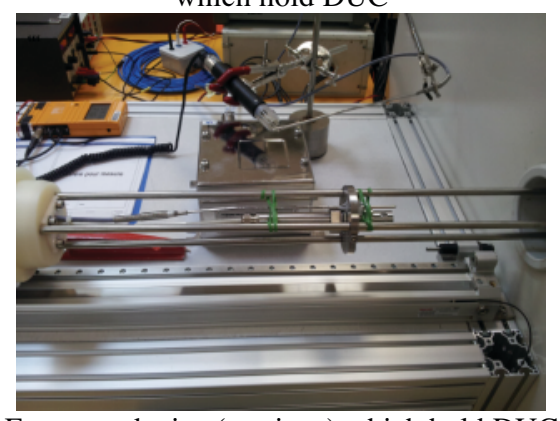

Focus on device (carriage) which hold DUC

Figure 15 Diagrams and pictures of facility

The test sequence is as follows:

- Stage 1: DUC is placed at the ambient conditions of the laboratory, i.e. $23^{\circ} \mathrm{C}-3^{\circ} \mathrm{C} /+4^{\circ} \mathrm{C}$, from $15 \%$ rh to $85 \%$ rh and atmospheric pressure during at least 30 minutes

- Stage 2: DUC power is switched off and moved into the climatic chamber set at $0^{\circ} \mathrm{C} \pm 2^{\circ} \mathrm{C}$, during 60 minutes

- Stage 3: DUC power is switched on and moved back to the ambient conditions of the laboratory, i.e. $23^{\circ} \mathrm{C}-3{ }^{\circ} \mathrm{C} / 44^{\circ} \mathrm{C}$, from $15 \%$ rh to $85 \%$ rh and atmospheric pressure.

- Stage 4: In such situation, the maximal value indicated by DUC is recorded $\left(U_{w, \text { meas }, 1}\right)$. During dwell time, of $48 \mathrm{~h}$, values indicated by DUC $\left(U_{w, \text { meas }, 2}\right)$ are recorded.

- Stage 5: Determination of dwell time which allows DUC to reach manufacturer specification.

If the DUC value is stable, the test sequence is repeated twice with DUC switched on at stage 2. DUC is tested without filter.
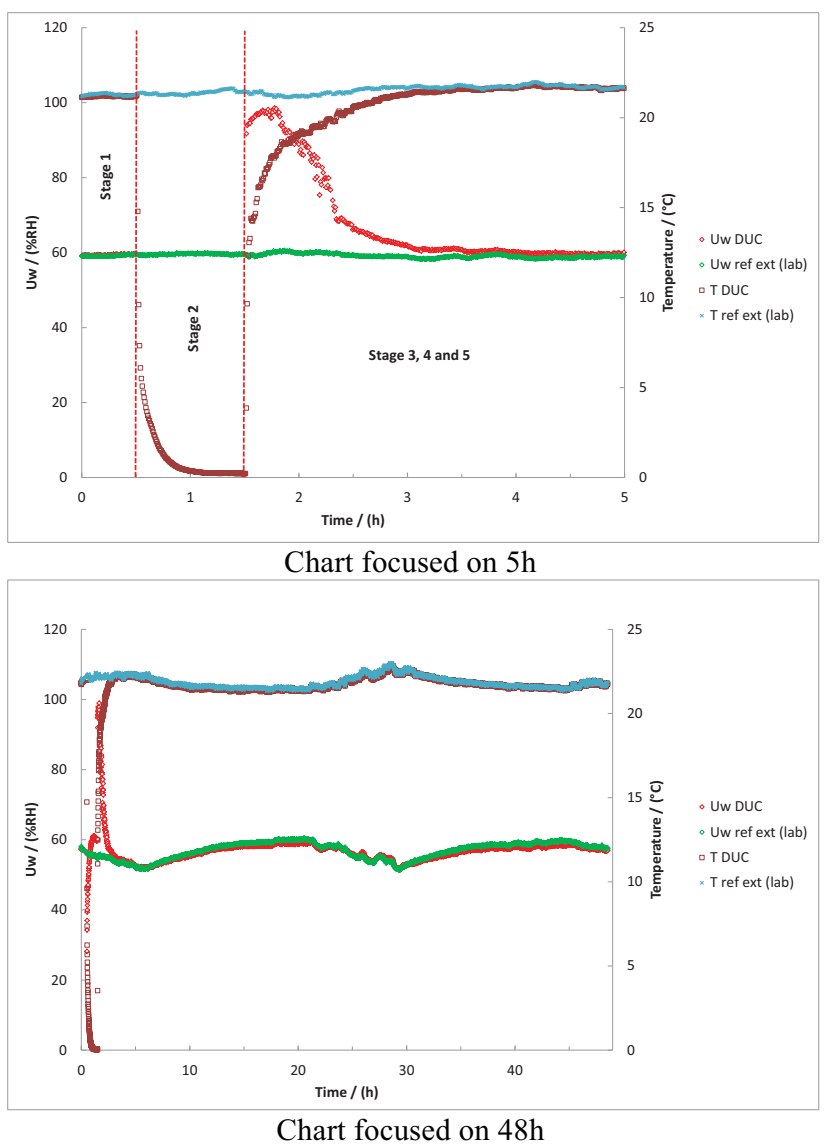

Figure 16 Sample response chart obtained during test "withstanding to condensation" - $\mathrm{U}_{\mathrm{w}}$ measured by DUC (red), temperature mesured with Pt100 close to DUC (brown), reference value for $U_{w}$ in the lab (green), ), reference value for reference temperature in the lab. (blue)

At ambient temperature, and at ambient humidity, DUC needs between 3 and 5 hours, after accidental condensation, in order to be close to manufacturer specifications.

\subsubsection{Immersion test}

The aim of this test is to qualify the resilience capability of the humidity probe consequently to an immersion in distilled water. The humidity probe is immersed in distilled water and after a dwell time, moved into ambient conditions of the laboratory, i.e. $23^{\circ} \mathrm{C}$ $3^{\circ} \mathrm{C} /+4^{\circ} \mathrm{C}$, from $15 \%$ rh to $85 \%$ rh and atmospheric pressure.

The calibration bench is composed by a vessel and a holding fixture (carriage) which allows the motion of DUC from the vessel to ambient conditions of the laboratory. The signal conditioner remains in the ambient 
conditions of the laboratory. Temperatures of ambient condition and distilled water are measured as close as possible to the DUC.
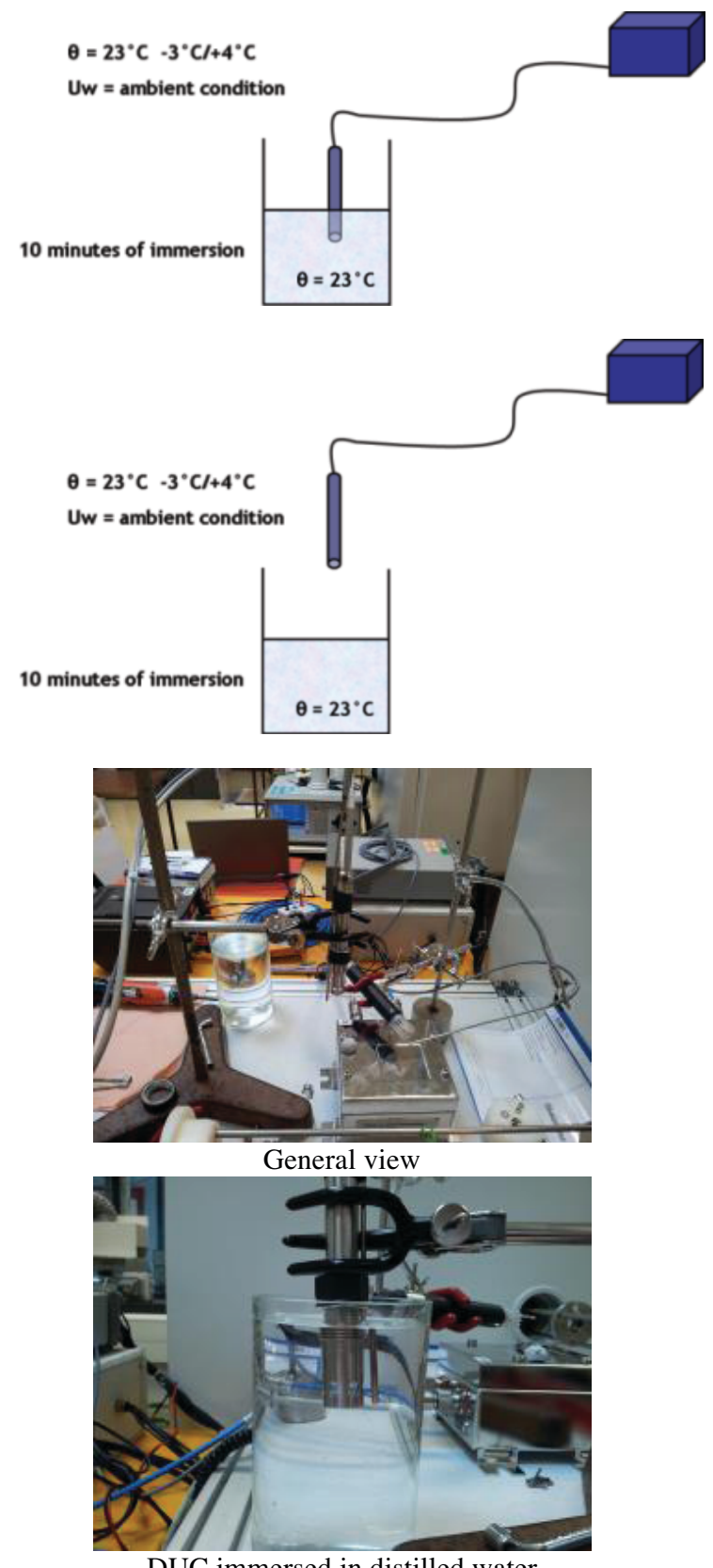

DUC immersed in distilled water

Figure 17 Diagrams and pictures of facility

The test sequence is as follows:

- Stage 1: DUC is stabilized at the ambient conditions of the laboratory, i.e. $23^{\circ} \mathrm{C}-3^{\circ} \mathrm{C} /+4^{\circ} \mathrm{C}$, from $24 \%$ rh to $85 \%$ rh and atmospheric pressure for at least 30 minutes. Deviation between ambient conditions and DUC value is determined.

- Stage 2: DUC power is switched off, then DUC is immersed in distilled water during 10 minutes.

- Stage 3: DUC is moved back to the ambient conditions of the laboratory, i.e. $23^{\circ} \mathrm{C}-3^{\circ} \mathrm{C} /+4^{\circ} \mathrm{C}$, from $24 \%$ rh to $85 \%$ rh and atmospheric pressure.

- Stage 4: Any residual droplets on the probe are removed. The cap and sensing element (I7000 module) are removed in order to eliminate water droplets and then reassembled. This stage should take few minutes only.

- Stage 5: Determination of the dwell time which allows DUC to reach manufacturer's specification. Deviation, between ambient conditions and DUC value is determined

If the time, to reach manufacturer's specification, is higher than $8 \mathrm{~h}$, DUC fails the test. If the DUC value is stable and the deviation observed in stage 1 is different to the deviation in stage 2 , the test sequence is repeated twice time. Thus DUC is tested without filter.

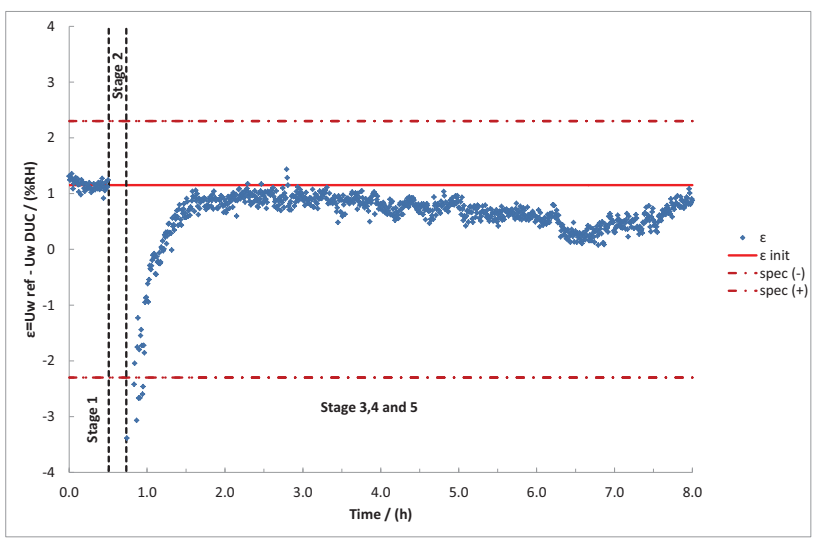

Figure 18 Sample response chart obtained during "immersion" test

At ambient temperature, and at ambient humidity, DUC needs between 2 and 5 hours, after an immersion in distilled water, in order to be close to initial value (before immersion).

\section{Conclusion}

This article has presented an implementation of the French standard NF X 15-113, with a focused on reference tests and extreme operating conditions tests.

For the needs of this implementation classical humid air generator, climatic chamber and new facilities have been used or developed. Thus this work proposed a way for following the French standard NF X 15-113 or for testing, in a wider context, humidity probes.

The results obtained with the six tested hygrometers were, in compliance, with manufacturer's specifications.

\section{Acknowledgements}

Authors would like to thank their colleagues, from Michell Instruments Ltd and CETIAT, for help and their involvement in this project.

\section{References}

1. NF X15-113 "Mesure de l'humidité relative de l'air - Hygromètre à variation d'impédance (capacitif et résistif)", Décembre 1997

NF X15-113 "Measurement of air humidity - 
Impedance variation hygrometer (capacitive and resistive)", December 1997

2. E. Georgin, B. Bondoux, et F. Bonjus, "Vers un principe de dilution pour la génération d'air humide au LNE-CETIAT", Proceedings CIM, 2011

3. F. Gonin, B. Blanquart, "Improvement of CETIAT humid air generator in low-range", $5^{\text {th }}$ ISHM, 2006

4. B. Cretinon, "The CETIAT standard humidity generator operating from $-60^{\circ} \mathrm{C}$ to $+70^{\circ} \mathrm{C}$ in dewpoint temperature". Proceedings $3^{\text {rd }}$ ISHM, 1998

5. E. Georgin, B. Blanquart, "Humid air generator in low range: qualification", Proceedings TEMPMEKO \& ISHM, 2010 